\title{
Origin and distribution of As along an W-E transect of Chile $\left(1^{\circ} \mathrm{S}\right)$
}

\author{
B. SePÚlVEdA ${ }^{1,}$ J. TAPIA ${ }^{2,3}$, M. BRAVO ${ }^{4}$ \\ ${ }^{1}$ Geología, UST, Santiago, Chile \\ ${ }^{2}$ Depto. Cs. Geológicas, UCN, Antofagasta, Chile \\ ${ }^{3}$ IGCP-707, UNESCO \\ ${ }^{4}$ Instituto de Química, PUCV, Valparaíso, Chile.
}

Due to water scarcity and naturally elevated As in waters of northern Chile, this study was undertaken to better understand the distribution and origin of As in surface water and sediments. Geologic, metallogenic, and climatic factors which might affect the geochemical distribution of As were also considered. The natural variability of As concentrations were evaluated through a geochemical baseline of surface water and sediments in an W-E transect comprising the Surire Salt Flat, Caritaya Dam, and Camarones River, all of which are located in the Arica and Parinacota Region of northern Chile ( 19ㅇ).

12 water samples were taken at the end of the wet season (end of March 2019) and 14 were collected during the dry season (July). Samples were filtered though a $0.22 \mu \mathrm{m}$ cellulose filter and were acidified in the field $(\mathrm{pH} 2)$. Arsenic quantification was made by an ICP-MS. 350 samples of the geochemical map of Sernageomin were used for sediment concentrations [1]. Statistics and distribution maps were used to established a baseline for As.

Despite the elevated baseline of As in the studied area (Table 1), the statistical analysis and distribution maps indicate that high concentrations in sediments are mostly from geogenic origins, with minor relation to anthropogenic factos such as mining activities near the outlet of the Camarones River. In surface water, As sources are geogenic and are proposed to be related to weathering of Miocene volcanic outcrops and thermal springs. Finally, at the Surire Salt Flat, As concentrations exhibit a wide range of concentrations (14 to $3995 \mu \mathrm{g} \cdot \mathrm{L}^{-1}$ ) due to the fact that it represents a hydraulic sink of highly variable composition and salinity [2].

Table 1. Proposed water and sediment baseline for As.

\begin{tabular}{lll}
\cline { 2 - 3 } & As $\left(\boldsymbol{\mu g} \cdot \mathbf{L}^{-1}\right)$ & As $\left(\mathbf{m g} \cdot \mathbf{k g}^{-1}\right)$ \\
\hline Baseline & $718-1210$ & $26-72$ \\
\hline
\end{tabular}

[1] Baeza, L., et al. 2014. Base de Datos de Geoquímica de sedimentos de la Hoja Arica, región de Arica y Parinacota (No. 02) [2] Risacher et al. (1999). Geoquímica de aguas en cuencas cerradas: I, II y III regiones - Chile, 37-55. 